ACADEMIA ROMÂNĂ

Revue Roumaine de Chimie

http://web.icf.ro/rrch/
Rev. Roum. Chim.,

2021, 66(3), 281-286

DOI: $10.33224 /$ rrch.2021.66.3.08

\title{
DEGRADATION OF BRILLIANT BLUE FCF THROUGH PHOTOLYSIS, IRRADIATION AND PHOTO-FENTON PROCESSES: A COMPARATIVE STUDY
}

\author{
Daniela NEGOESCU, ${ }^{\mathrm{a}}$ Petruța OANCEA, ${ }^{\mathrm{b},{ }^{*}}$ Adina RĂDUCAN ${ }^{\mathrm{b}}$ and Mihaela PUIU ${ }^{\mathrm{b}}$ \\ a "Ilie Murgulescu" Institute of Physical Chemistry, Roumanian Academy, 202 Splaiul Independentei, 060021 Bucharest, Roumania \\ ${ }^{\mathrm{b}}$ Department of Physical Chemistry, Faculty of Chemistry, University of Bucharest, Bd. Regina Elisabeta, 4-12, \\ Bucharest 030018, Roumania
}

In this work we performed a comparative study regarding the performance characteristics of three photochemical treatments for Brilliant Blue degradation: photolysis (only UV radiation), irradiation in the presence of $\mathrm{H}_{2} \mathrm{O}_{2}\left(\mathrm{H}_{2} \mathrm{O}_{2} / \mathrm{UV}\right)$, photo-Fenton reaction $\left(\mathrm{Fe}^{2+} / \mathrm{H}_{2} \mathrm{O}_{2} / \mathrm{UV}\right)$. The kinetic analysis revealed that $\mathrm{BB}$ degradation follows an apparent first order kinetics. The examination of the estimated rate constants and the degradation efficiencies revealed the superior performance of the photoFenton oxidation, which may be due an increased gain of reactive oxygen species species comparative to the UV or $\mathrm{UV} / \mathrm{H}_{2} \mathrm{O}_{2}$ treatment.

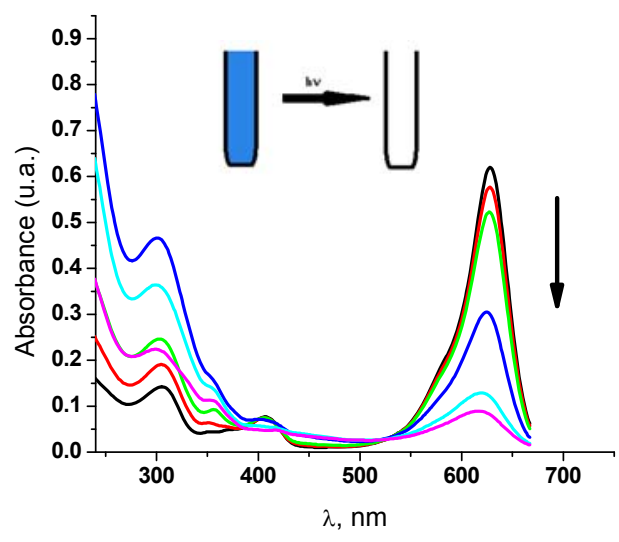

\section{INTRODUCTION}

Dyes are complex aromatic compounds that are overly used in many industries such as food, textiles, and printing. However, they also cause environmental issues, being life- and health threating of living organisms due to their complex structure and enhanced chemical stability. ${ }^{1,2}$ Therefore, dye removal or at least dye degradation to non-harmful compounds, is a topic of major concern. Brilliant Blue FCF (BB), a triarylmethane dye, is used in food industry, rubber, paper, plastics, medications, and cosmetics. ${ }^{3}$ There are several conventional methods dedicated to the removal of synthetic dyes from waste: electrochemical oxidation, ${ }^{4}$ physical adsorption, chemical oxidation, and chemical coagulation/ precipitation..$^{5-7}$ These methods are not destructive, they only transfer the pollutant from one phase to another. Mineralization of dyes by industrial effluents can be achieved in advanced oxidation processes (AOPs). ${ }^{8-11} \mathrm{UV} / \mathrm{H}_{2} \mathrm{O}_{2}$ photolysis is an efficient treatment for pollutants' removal displaying significant advantages such as no sludge production, simplicity of operation and low cost; besides all that, $\mathrm{H}_{2} \mathrm{O}_{2}$ is an environmental-friendly

*Corresponding author: petrutaoancea73@yahoo.com 
oxidant. Even if the discovery of the Fenton reagent, a mixture of hydrogen peroxide and ferrous ions, traces back to the late $19^{\text {th }}$ century, its application in oxidative destruction of toxic compounds did not begin until the late 1960s. ${ }^{12-14}$ Reactive oxygen species (ROS) are generated during the Fenton process through the chemical reactions (eqs. 1-2): ${ }^{15}$

$$
\begin{aligned}
\mathrm{Fe}^{2+}+\mathrm{H}_{2} \mathrm{O}_{2} & \rightarrow \mathrm{Fe}^{3+}+\mathrm{HO}+\mathrm{OH}^{-} \\
\mathrm{Fe}^{3+}+\mathrm{H}_{2} \mathrm{O} & \rightarrow \mathrm{Fe}(\mathrm{HO})^{2+}+\mathrm{H}^{+}
\end{aligned}
$$

In addition to the above reactions the photoFenton ensures the formation of hydroxyl radicals according to the photochemical reactions (eqs. $3-5$ ):

$$
\begin{gathered}
\mathrm{Fe}(\mathrm{OH})^{2+}+\mathrm{h} v \rightarrow \mathrm{Fe}^{2+}+\mathrm{HO}^{\cdot} \\
\mathrm{Fe}^{3+}+\mathrm{H}_{2} \mathrm{O}+\mathrm{h} v \rightarrow \mathrm{HO}+\mathrm{Fe}^{2+}+\mathrm{H}^{+} \\
\mathrm{H}_{2} \mathrm{O}_{2}+\mathrm{h} v \rightarrow 2 \mathrm{HO}
\end{gathered}
$$

There are not many studies reporting photodegradation of Brilliant Blue. Gosetti et al. ${ }^{16}$ evaluated the oxidative degradation of $\mathrm{BB}$ by addition of potassium persulfate at different persulfate to dye molar ratios under natural sunlight irradiation. Parvin et al. ${ }^{17}$ studied photocatalytic degradation of Brilliant Blue FCF using silver-dopped $\mathrm{ZnO}$ designed particles. It is worth mentioning several fast and effective degradation of Brilliant Blue in aqueous medium such as ozonation ${ }^{18}$ and photolytic oxidation with $\mathrm{H} 2 \mathrm{O} 2 .{ }^{19}$ The aim of our work was the perform and to optimize the photodegradation degradation of BB either through UV induced $\mathrm{H}_{2} \mathrm{O}_{2}$ photolysis, or by photo-Fenton oxidation at $\mathrm{pH} 3$. The method was based on the monitoring the decrease of absorbance during the irradiation time. In this context we explored the decay kinetics of BB and the decolourization degree at settled experimental conditions. We evaluated the effect of the initial concentration of hydrogen peroxide and irradiation time on the decolourization rate.

\section{RESULTS AND DISCUSSION}

As previously mentioned, the photodegradation of BB was followed under different experimental condition: photolysis (only UV radiation), irradiation in the presence of $\mathrm{H}_{2} \mathrm{O}_{2}\left(\mathrm{H}_{2} \mathrm{O}_{2} / \mathrm{UV}\right)$, photo-Fenton reaction $\left(\mathrm{Fe}^{2+} / \mathrm{H}_{2} \mathrm{O}_{2} / \mathrm{UV}\right)$ (Fig. 1). The normalized form of the exponential decay equation was fitted onto the experimental data absorbance $v s$. time aiming the estimation of the decolourization kinetic constants $k$ (eq. 6).

$$
\frac{A}{A_{R}}=\exp \{-k t i
$$

Here $\mathrm{A}_{0}$ is the absorbance at the beginning of the experiment and $\mathrm{A}$ is the instantaneous absorbance (at a certain time value). Absorbances were recorded at specific wavelength $\lambda=630 \mathrm{~nm}$.

The fastest decolourization was observed in the case of the photo-Fenton system, while the simple irradiation produced low decolourization degrees within an hour. The preliminary examination of the extended kinetic curves indicate that 1) the decolourization kinetic constants decrease in the order $k_{\mathrm{Fe} 2+/ \mathrm{H} 2 \mathrm{O} / \mathrm{UV}}>k_{\mathrm{H} 2 \mathrm{O} 2 / \mathrm{UV}}>k_{\mathrm{UV}}$ and 2) $\mathrm{H}_{2} \mathrm{O}_{2}$ plays an important role as a source of $\bullet \mathrm{OH}$ both in $\mathrm{H}_{2} \mathrm{O}_{2} / \mathrm{UV}$ and photo-Fenton reaction.

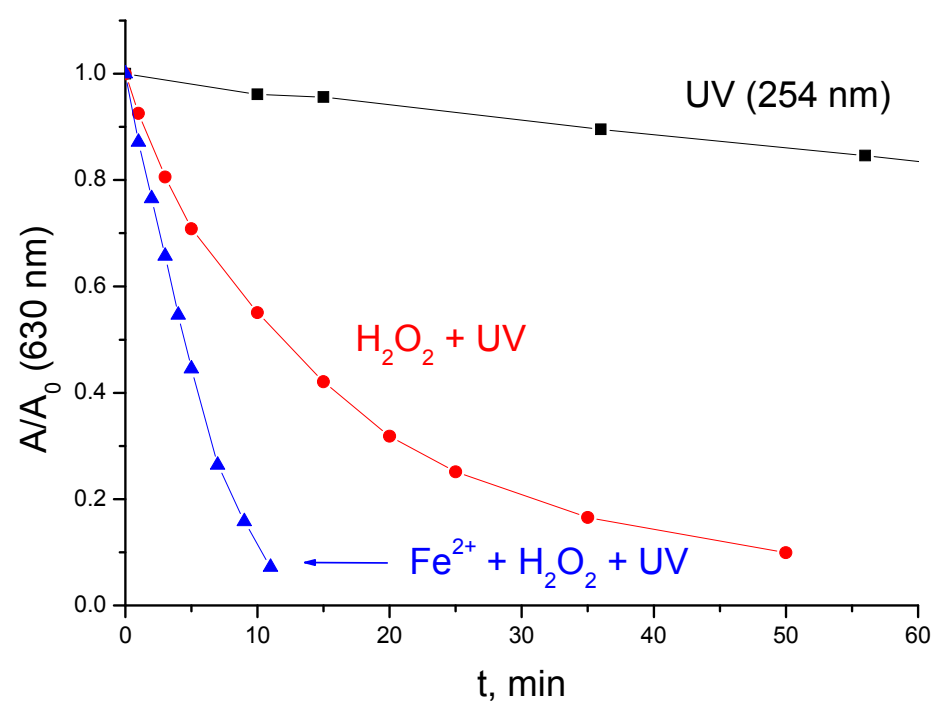

Fig. 1 - Comparative study on the efficiency of three photodegradation methods based on the extended kinetic curves absorbance vs. time. $[\mathrm{BB}]_{0}=1.0 \times 10^{-5} \mathrm{M},\left[\mathrm{H}_{2} \mathrm{O}_{2}\right]_{0}=4.0 \times 10^{-4} \mathrm{M}\left[\mathrm{Fe}^{2+}\right]_{0}=1 \times 10^{-3} \mathrm{M}$. 


\section{Influence of $\mathrm{H}_{2} \mathrm{O}_{2}$ in irradiation experiments}

The simple preliminary assay started from $1.0 \times 10^{-5} \mathrm{M} \mathrm{BB}$ and a ten-fold excess of $\mathrm{H}_{2} \mathrm{O}_{2}$. At settled times, $3 \mathrm{~mL}$ from the reaction mixture were extracted and analysed through UV-VIS measurements. After 20 minutes only $10 \%$ BB was degraded in the absence of $\mathrm{H}_{2} \mathrm{O}_{2}$, while around $70 \%$ dye faded using the $\mathrm{UV} / \mathrm{H}_{2} \mathrm{O}_{2}$ system. As shown in Fig. 2, a plot of $\ln \left(\mathrm{A}_{0} / \mathrm{A}\right)$ vs. irradiation time leaded to a linear dependence, characteristic to a pseudo-first order kinetics. Here, the slopes represent the decolourization kinetic constants: $k=2.93 \times 10^{-3} \min ^{-1}$ (with a determination coefficient, $\mathrm{R}^{2}=0.9997$ ) for the $\mathrm{BB} / \mathrm{UV}$ system and $k=51.0 \times 10^{-3} \min ^{-1}\left(\mathrm{R}^{2}=0.9943\right)$ for the $\mathrm{BB} / \mathrm{UV} / \mathrm{H}_{2} \mathrm{O}_{2}$ system.

The increase of the rate constant in the case of the $\mathrm{BB} / \mathrm{UV} / \mathrm{H}_{2} \mathrm{O}_{2}$ system can be explained by the enhanced production of hydroxyl radicals $(\mathrm{OH})$ during the UV irradiation of hydrogen peroxide in aqueous solution, according to the sequence of eqs. 7-9:

$$
\begin{gathered}
\mathrm{H}_{2} \mathrm{O}_{2}+h v \longrightarrow 2^{\bullet} \mathrm{OH} \\
\mathrm{BB}+{ }^{\bullet} \mathrm{OH} \longrightarrow \text { Intermediate } \\
\text { Intermediate }+{ }^{\bullet} \mathrm{OH} \longrightarrow \text { Final products }
\end{gathered}
$$

Next, the $\mathrm{UV} / \mathrm{H}_{2} \mathrm{O}_{2}$ oxidation was performed by varying $\mathrm{H}_{2} \mathrm{O}_{2}$ concentration within $1-5 \times 10^{-4} \mathrm{M}$, at constant Brilliant Blue concentration $\left(1 \times 10^{-5}\right.$ M). The estimated pseudo-first-rate constants, together with the percentage degradation efficiency $(\eta \%$, defined in eq. 10) after $20 \mathrm{~min}$, are summarized Table 1.

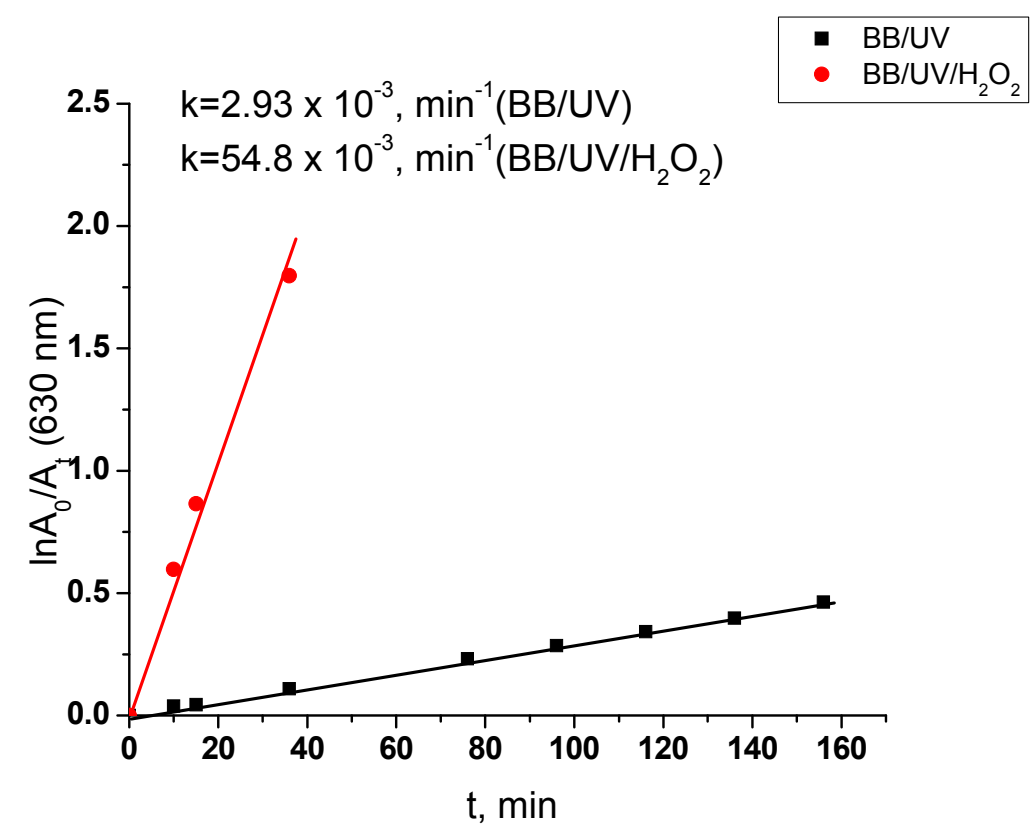

Fig. 2 - Evidence of the striking influence of $\mathrm{H}_{2} \mathrm{O}_{2}$ on the kinetics of Brilliant Blue photodegradation $[\mathrm{BB}]_{0}=1.0 \times 10^{-5} \mathrm{M},\left[\mathrm{H}_{2} \mathrm{O}_{2}\right]_{0}=1.0 \times 10^{-4} \mathrm{M}$.

Table 1

Performance parameters of Brilliant Blue photodegradation using $\mathrm{UV} / \mathrm{H}_{2} \mathrm{O}_{2}$ system

\begin{tabular}{cccc}
\hline$\left[\mathbf{H}_{\mathbf{2}} \mathbf{O}_{\mathbf{2}}\right]_{\mathbf{0}} \times \mathbf{1 0}^{\mathbf{4}} \mathbf{( M )}$ & $\boldsymbol{k}\left(\mathbf{m i n}^{-\mathbf{1}}\right) \times \mathbf{1 0}^{\mathbf{2}}$ & $\mathbf{t}_{\mathbf{1 / 2}} \mathbf{( \mathbf { m i n } )}$ & $\boldsymbol{\eta} \mathbf{\%}$ \\
\hline 1 & $5.48 \pm 0.019$ & 12.64 & 69 \\
2 & $11.18 \pm 0.085$ & 6.19 & 89 \\
4 & $14.6 \pm 0.062$ & 4.74 & 93 \\
5 & $13.2 \pm 0.074$ & 5.25 & 90 \\
\hline
\end{tabular}

$t_{1 / 2}$ - half-life 


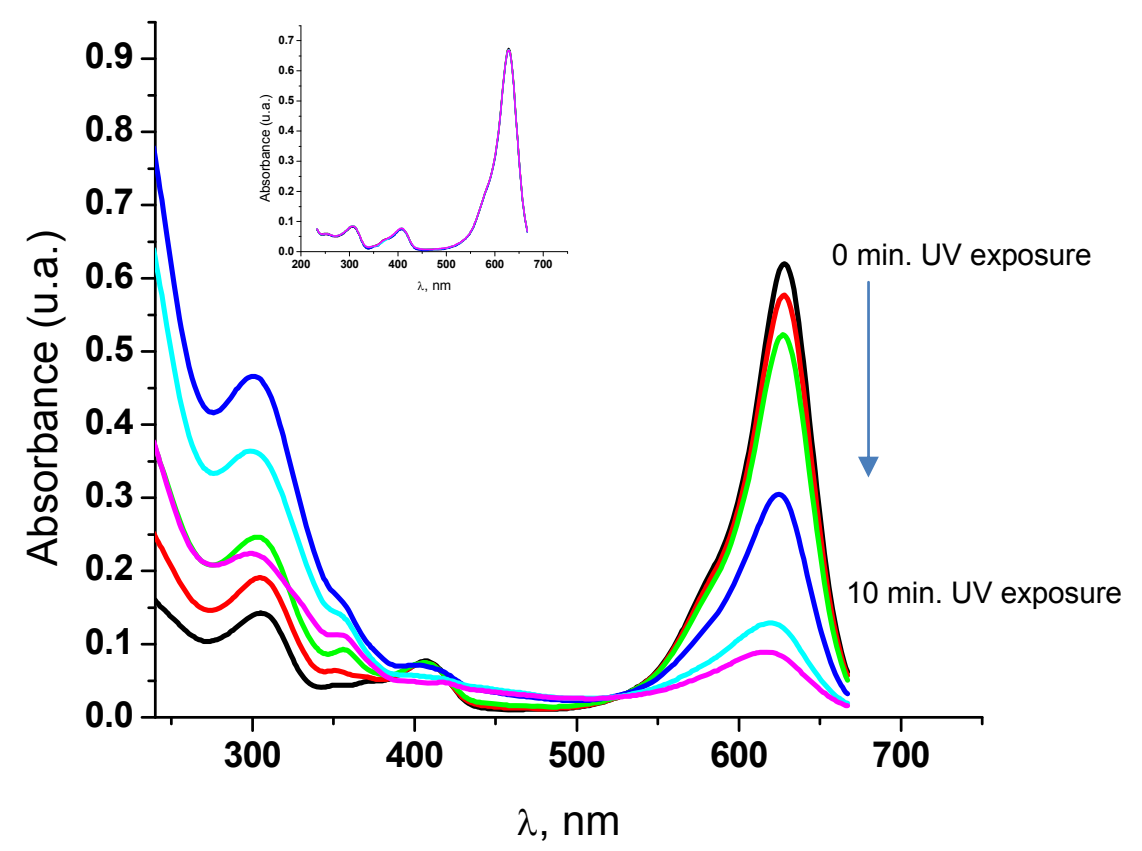

Fig. 3 - UV-Vis absorption spectra of an aqueous Brilliant Blue solution during degradation with the Photo-Fenton process: $[\mathrm{BB}]=1.0 \times 10^{-5} \mathrm{M},\left[\mathrm{H}_{2} \mathrm{O}_{2}\right]=1.0 \times 10^{-4} \mathrm{M}\left[\mathrm{Fe}^{2+}\right]=1 \times 10^{-3} \mathrm{M}$. Insert: Fenton degradation of BB.

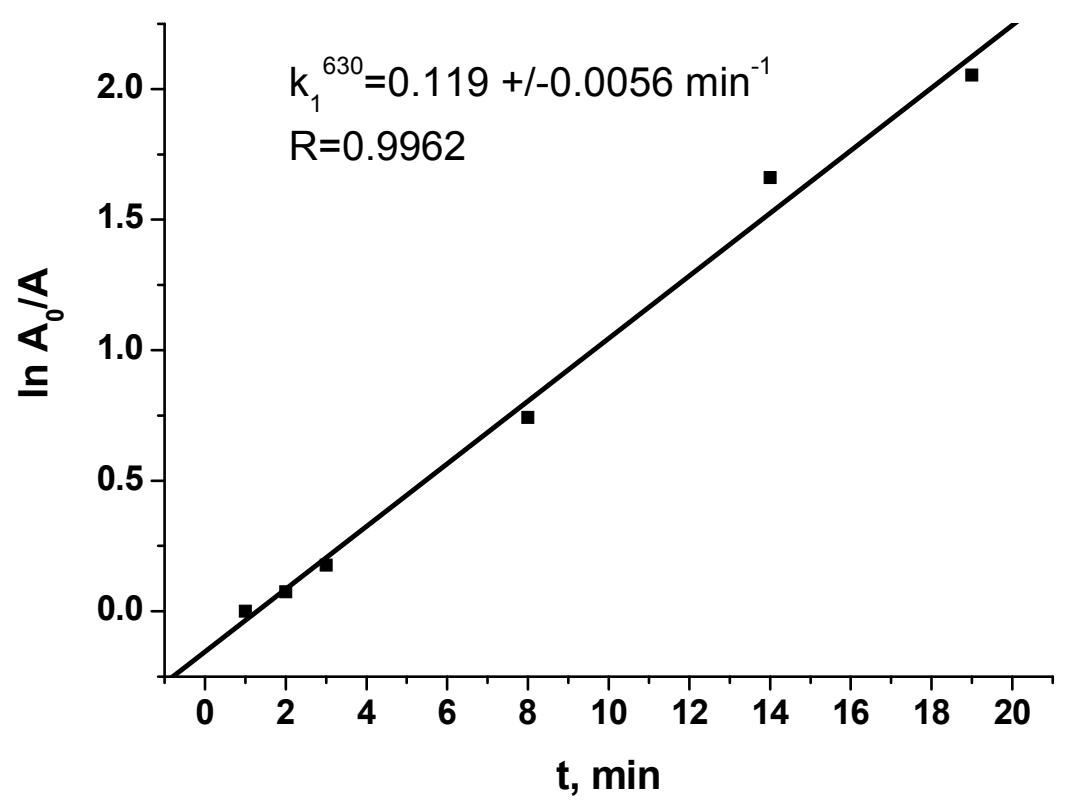

Fig. 4 - First-order reaction kinetics for the degradation of Brilliant Blue the Photo-Fenton process: $[\mathrm{BB}]=1.0 \times 10^{-5} \mathrm{M},\left[\mathrm{H}_{2} \mathrm{O}_{2}\right]=1.0 \times 10^{-4} \mathrm{M}\left[\mathrm{Fe}^{2+}\right]=1 \times 10^{-3} \mathrm{M}$.

The rate constant increases with the increase of $\mathrm{H}_{2} \mathrm{O}_{2}$ concentration up to $4 \times 10^{-4} \mathrm{M}$, but decreases at $5 \times 10^{-4} \mathrm{M}$. Similar effects were reported by other author $\mathrm{s}^{20-21}$ for the degradation of different dyes.

The increasing of $\mathrm{H}_{2} \mathrm{O}_{2}$ concentration and keeping constant $\mathrm{FeSO}_{4}$ and $\mathrm{BB}$ concentrations lead to a rapid discoloration of the solution. In this case the reaction rate constant could not be calculated due to the very short degradation times.

\section{The effect of UV irradiation on BB degradation with the photo-Fenton system}

The experiments were carried out in the absence and the presence of light employing the $\mathrm{Fe}^{2+} / \mathrm{H}_{2} \mathrm{O}_{2}$ (Fenton reagent). According to the literature, ${ }^{22}$ the optimum $\mathrm{pH}$ is 3 . At $\mathrm{pH}=3, \mathrm{Fe}^{3+}$ and $\mathrm{Fe}(\mathrm{OH})^{2+}$ complex ions co-exist in equal proportion, which grant enhanced light absorption 
and high quantum yield for hydroxyl radical generation. The increase of $\mathrm{pH}$ lead to a decrease of the concentration of $\mathrm{OH}$ in solution, due to the coagulation of $\mathrm{Fe}^{3+}$ and $\mathrm{Fe}^{2+}$ complexes. Moreover, at higher $\mathrm{pH}$ value precipitation of ferrous ions as oxyhydroxide may occur, reducing the concentration of hydroxyl radicals and thus affecting the degradation rate. ${ }^{23}$ The examination of UV-VIS spectra of BB during the degradation with Fenton and photo-Fenton system are presented in Fig. 3.

It was noticed that in the absence of UV light, $\mathrm{Fe}^{2+} / \mathrm{H}_{2} \mathrm{O}_{2}$ system is not able to degrade the dye, probably due to the small amount of $\bullet \mathrm{OH}$ radicals generated in the "classic" Fenton reaction (eqs. 1 and 2). After $60 \mathrm{~min}$ no noticeable change in the BB spectra was observed. Then, after 10 min UV exposure, an $88 \%$ percent of dye faded, due to the contribution of the steps 3-5, which increase $\mathrm{OH}$ concentration. The rate constant was estimated by the pseudo-first order model onto data $\ln \left(\mathrm{A}_{0} / \mathrm{A}\right)$ vs. time (Fig. 4).

\section{EXPERIMENTAL}

\section{Materials}

All other reagents (Brilliant Blue FCF, $\mathrm{FeSO}_{4}, \mathrm{H}_{2} \mathrm{O}_{2}$ ) obtained from Sigma were of analytical grade and were used as received without further purification. $\mathrm{H}_{2} \mathrm{O}_{2} 30 \%$ was diluted and the concentration was measured spectr0photometrically with $\varepsilon_{240 \mathrm{~nm}}=39.4 \mathrm{M}^{-1} \mathrm{~cm}^{-1}$. ${ }^{24}$

\section{Photodegradation experiments}

Brilliant Blue FCF samples $(3 \mathrm{~mL})$ was exposed to an artificial source, the low-pressure $\mathrm{Hg}$ lamp of $150 \mathrm{~W}$. The incident photonic flow was determined by ferrioxalate actinometry. ${ }^{25}$ We found a value of $1.92 \times 10-6$ einstein $\mathrm{s}^{-1}$. The UV-vis spectra of dye were recorded from 200 to $700 \mathrm{~nm}$ using a UV-vis spectrophotometer (Pye Unicam a Helios) with a spectrometric quartz cell $(1 \mathrm{~cm}$ path length). The maximum absorbance wavelength $(\lambda \max )$ of brilliant is 630 $\mathrm{nm}$. The $\mathrm{pH}$ of the solution was measured with a Radiometer pH-meter with glass electrode E11M001. Data were processed using the ORIGIN 8.0 software.

\section{CONCLUSIONS}

In this work, we performed and optimized the oxidative treatments for Brilliant Blue FCF decolourization using $\mathrm{UV} / \mathrm{H}_{2} \mathrm{O}_{2}$ and $\mathrm{Fe}^{2+} / \mathrm{H}_{2} \mathrm{O}_{2}$ /UV systems. It was noticed that the degradation of BB with both systems follow apparent first-order kinetics. The examination of the estimated rate constants and the degradation efficiencies revealed the superior performance of the photo-Fenton oxidation, which may be due an increased gain of ROS species comparative to the $\mathrm{UV} / \mathrm{H}_{2} \mathrm{O}_{2}$ treatment. The increase of the $\mathrm{H}_{2} \mathrm{O}_{2}$ concentration caused a significant augmentation of the rate constant, but only up to $4.0 \times 10^{-4} \mathrm{M}$. Above this value, the rate constant dropped, probably due to the scavenging effect of excess $\mathrm{H}_{2} \mathrm{O}_{2}$ and $\cdot \mathrm{OH}$ radicals.

\section{REFERENCES}

1. X. Zhang, Z. Geng, J. Jian, Y. He, Z. Lu, X. Liu and H. Yuan, Catalysts, 2020, 10, 293-298.

2. S. A. Phaltane, S. A.Vanalakar, T. S. Bhat, P. S. Patil, S. D. Sartale and L. D. Kadam, J. Mater. Sci. Mater. Electron., 2017, 28, 8186-8191.

3. V. K. Gupta, R. Jain and S.Vorshney, J. Colloid Interface Sci., 2007, 312, 292-296.

4. N. Daneshvar, D. Salari and D. Aber, J. Hazard. Mater. $B, \mathbf{2 0 0 2}, 94,49-61$.

5. N. Daneshvar, H. Ashassi-Sorkhabi and A.Tizpar, Sep. Purif. Technol., 2003, 31,153-162.

6. E. El Qada, S. Allen and G. Walker, Chem. Eng. J., 2008, 135,174-184.

7. V. K. Gupta, R. Jain, A. Nayak, S. Agarwal and M. Shrivastova, Mat. Sci. Eng. C, 2011, 31, 1062-1067.

8. V. K. Gupta, R. Jain, A. Mittal, T. A. Saleh., A. Nayak, S. Agarwal and S. Sikarwar, Mat. Sci. Eng. C, 2012. 32, $12-17$.

9. V. K. Gupta, D. Pathania, S. Agarwal and P. Singh, J. Hazard. Mater. B, 2012, 243,179-186.

10. C. T. Faragoso, R. Battisti, C. Miranda and P. C. De Jesus, J. Molec. Catal. A: Chem., 2009, 301, 93-97.

11. M. Kitis, C. D. Adams and G. T. Daigger. Wat. Res. 1999, 33, 2561-2568.

12. J. Yoan, Y. Lee and S. Kim, Wat. Sci. Technol., 2001, 44, 15-21.

13. M. C. Lu, C. J. Lin, C. H. Liao, W. P. Ting and R. Y. Huang, Water Sci. Technol., 2001, 44, 327-32.

14. P. L. Huston, J. J. Pignatello, Water Res., 1999, 33, 1238-1246.

15. F. Gosetti, V. Gianotti, S. Angioi, S. Polati, E. Marengo and M. C. Gennaro, J. of Chromatography A, 2004, 1054, 379-387.

16. T. Parvin, N. Keerthiraj, I. A. Ibrahim, S. Phanichphant and K. Byrappa, Int. J. Photoenergy, 2012, 1-8.

17. Cardoso da Silva, G. L. Bispo, S. P. Pavanelli, R. J. de Cássia, F. Afonso and R. Augusti, Mass Spectrom. 2012, 26, 1305-1310.

18. S. B. Bukallah, M. A. Rauf and S. S. Ashraf, Dyes Pigments, 2007, 72, 353-359.

19. M. A. Rauf, S. Ashraf and S. N. Alhadrami, Dyes Pigments, 2005, 66, 197-203.

20. P. Oancea and V. Meltzer, Chem. Pap., 2014, 68, 105111. 
21. A. M. El-Dein, J. A. Libra and U. Wiesmann, Chemosphere, 2003, 52, 1069-1077.

22. L. G. Devi, K. S. A. Raju, S. G. Kumar and K. E. Rajashekhar. J. Taiwan Inst. Chem. Eng., 2011, 42, 341349.

23. P. Oancea and V. Meltzer, J. Taiwan Inst. Chem. Eng., 2013, 44, 990-994.
24. H. Theorell and A. Ehrenberg, Arch. Biochem. Biophys., 1952, 41, 462-474.

25. C. G Hachard and C. H. Parker, "A new sensitive actinometer", Proceedings of Royal Society A, London, $1956,518-536$. 